\title{
Targeting Morphine-Responsive Neurons: Generation of a Knock-In Mouse Line Expressing Cre Recombinase from the Mu-Opioid Receptor Gene Locus
}

\author{
Julie Bailly, ${ }^{1}$ Natalie Del Rossi, ${ }^{1}$ Léonie Runtz, ${ }^{1}$ Jing-Jing Li, ${ }^{1}$ DaWoon Park, ${ }^{1}$ Grégory Scherrer, ${ }^{2,3}$ \\ Arnaud Tanti, ${ }^{1}{ }^{\circledR}$ Marie-Christine Birling, ${ }^{4}{ }^{\circledR}$ Emmanuel Darcq, ${ }^{1}$ and ${ }^{\circledR}$ Brigitte L. Kieffer ${ }^{1}$
}

https://doi.org/10.1523/ENEURO.0433-19.2020

${ }^{1}$ Department of Psychiatry, McGill University, Douglas Hospital Research Centre, Montreal, Quebec H4H 1R3, Canada, ${ }^{2}$ Department of Cell Biology and Physiology, UNC Neuroscience Center, The University of North Carolina at Chapel Hill, Chapel Hill, NC 27599, USA, ${ }^{3} \mathrm{New}$ York Stem Cell Foundation - Robertson Investigator, and ${ }^{4}$ CELPHEDIA, PHENOMIN, Institut Clinique de la Souris (ICS), 67404 Illkirch-Graffenstaden, France

\begin{abstract}
The mu-opioid receptor (MOR) modulates nociceptive pathways and reward processing, and mediates the strong analgesic and addictive properties of both medicinal as well as abused opioid drugs. MOR function has been extensively studied, and tools to manipulate or visualize the receptor protein are available. However, circuit mechanisms underlying MOR-mediated effects are less known, because genetic access to MOR-expressing neurons is lacking. Here we report the generation of a knock-in Oprm1-Cre mouse line, which allows targeting and manipulating MOR opioid-responsive neurons. A cDNA encoding a T2A cleavable peptide and Cre recombinase fused to enhanced green fluorescent protein (EGFP/Cre) was inserted downstream of the Oprm1 gene sequence. The resulting Oprm1-Cre line shows intact Oprm1 gene transcription. MOR and EGFP/Cre proteins are coexpressed in the same neurons, and localized in cytoplasmic and nuclear compartments, respectively. MOR signaling is unaltered, demonstrated by maintained DAMGO-induced G-protein activation, and in vivo MOR function is preserved as indicated by normal morphine-induced analgesia, hyperlocomotion, and sensitization. The Cre recombinase efficiently drives the expression of Cre-dependent reporter genes, shown by local virally mediated expression in the medial habenula and brain-wide fluorescence on breeding with tdTomato reporter mice, the latter showing a distribution patterns typical of MOR expression. Finally, we demonstrate that optogenetic activation of MOR neurons in the ventral tegmental area of Oprm1-Cre mice evokes strong avoidance behavior, as anticipated from the literature. The Oprm1-Cre line is therefore an excellent tool for both mapping and functional studies of MOR-positive neurons, and will be of broad interest for opioid, pain, and addiction research.
\end{abstract}

Key words: cell-specific gene targeting; Cre-loxP system; enkephalins; knock-in mice; morphine; Oprm1 gene

\section{Significance Statement}

Here we develop an innovative tool to characterize circuit mechanisms underlying opioid actions, which may help the research communities to improve the knowledge on circuitry adaptation and response to opioids. The tool is particularly relevant in the context of the current opioid crisis. Medicinal and abused opioids act primarily on mu-opioid receptor (MOR), and we developed here a Cre mouse line to specifically target and manipulate MOR-expressing neurons. This resource has huge potential for mapping, molecular characterization, and functional studies of opioid-responsive neurons.

Received October 17, 2019; accepted April 9, 2020; First published May 7, 2020.

The authors declare no competing financial interests.
Author contributions: J.B., G.S., M.-C.B., E.D., and B.L.K. designed research; J.B., N.D.R., L.R., J.-J.L., D.P., and A.T. performed research; J.B. and M.-C.B. contributed unpublished reagents/analytic tools; J.B., N.D.R., L.R., J.-J.L., E.D., and B.L.K. analyzed data; J.B., E.D., and B.L.K. wrote the paper. 


\section{Introduction}

The mu-opioid receptor (MOR) is the primary molecular target for medicinal and abused opioids. This receptor mediates both the unrivaled analgesic properties of opioids for pain treatment, and their adverse effects, including notably their strong addictive potential (Matthes et al., 1996; Darcq and Kieffer, 2018), which is driving the current opioid epidemic (World Health Organization, 2017; Volkow and Koroshetz, 2019). Under physiological conditions, MOR is activated by endogenous opioid peptides, and modulates nociceptive pathways (Corder et al., 2018), respiration centers (Levitt and Williams, 2018), and brain circuits that process reward and emotions (Contet et al., 2004; Lutz and Kieffer, 2013). Although the essential role of MOR in pain, drug abuse, and mood disorders is well established, and receptor adaptations to chronic opioid use have been well studied at the cellular level (Williams et al., 2013; Cahill et al., 2016), circuit mechanisms underlying MOR function (Darcq and Kieffer, 2018) and the regulation of neuronal communication driven by MOR (Mechling et al., 2016) and MOR agonists (Nasseef et al., 2019) are poorly understood.

Several genetic mouse tools have been developed to study MOR function, but have not given genetic access to MOR-expressing neurons as yet. A knock-in MORmCherry mouse line was developed to map MOR protein expression throughout the nervous system brain (Gardon et al., 2014; Erbs et al., 2015), and it allows speculation about the circuit mechanisms driving MORmediated behaviors. Mice with a floxed Oprm1 gene have permitted receptor deletion in targeted neurons from nociceptive (Weibel et al., 2013) and reward (Charbogne et al., 2017) pathways, uncovering some circuit mechanisms of MOR-mediated pain control and motivation. A next step to understand MOR physiology, and to fully investigate neural dysfunctions associated with opioid drug use, misuse, and abuse, is to study and manipulate the activity of MOR-expressing neurons that directly respond to both exogenous and endogenous mu-opioids.

This work was supported by the National Institutes of Health (National Institute of Drug Abuse Grant DA-05010 to B.L.K.; and National Institute on Alcohol Abuse and Alcoholism Grant 16658 to B.L.K.), the Canada Fund for Innovation, and the Canada Research Chairs to E.D. and B.L.K., and by the Wallonie-Bruxelles International (to J.B.).

Acknowledgments: We thank the staff at the animal facility of the Neurophenotyping Center and the Molecular and Cellular Microscopy Platform of the Douglas Mental Health University Institute (Montréal, Canada) for microscope usage. We also thank Kai-Florian Storch, Lei Zhu and Naguib Mechawar for technical support. G.S. is a New York Stem Cell Foundation Robertson Investigator. In addition, we thank the Mouse Clinic Institute (Illkirch, France) for generating Oprm1-Cre mice. Finally, we thank the National Institute on Drug Abuse Supply Drug Program for providing morphine.

Correspondence should be addressed to Brigitte L. Kieffer at brigitte. kieffer@douglas.mcgill.ca.

https://doi.org/10.1523/ENEURO.0433-19.2020

Copyright @ 2020 Bailly et al.

This is an open-access article distributed under the terms of the Creative Commons Attribution 4.0 International license, which permits unrestricted use, distribution and reproduction in any medium provided that the original work is properly attributed.
To this aim, the best approach is to create a mouse line expressing the Cre recombinase in MOR-expressing neurons. Here we report the generation of a line expressing the Cre recombinase under the control of the Oprm1 gene (encoding MOR) promoter, and present molecular and behavioral characterization of this mouse line (Oprm1-Cre line). We also show successful labeling of MOR-positive neurons using a fluorescent Cre-dependent reporter mouse line. We finally demonstrate that optogenetic stimulation of MOR-positive neurons in the ventral tegmental area is sufficient to induce strong avoidance behavior, as anticipated from the literature. The line fulfills all the criteria to successfully study and manipulate MOR neurons.

\section{Materials and Methods}

\section{Animals}

The Oprm1-Cre knock-in mouse line was generated by homologous recombination to express a Cre recombinase under the control of the Oprm1 promoter. In this mouse line, a cDNA encoding a functional EGFP/Cre recombinase fusion protein was inserted into exon 4 of the MOR gene, in frame and $5^{\prime}$ of the stop codon, as described in the studies by Gardon et al. (2014) and Erbs et al. (2015). The EGFP/ Cre cDNA was generated by cloning the Cre cDNA [a gift from Daniel Metzger, Institut de Génétique et de Biologie Moléculaire et Cellulaire (IGBMC), Illkirch, France] by PCR into the Bglll and EcoRI sites of the pEGFP-C2 plasmid (Clontech/Addgene), resulting in a 7 aa linker SGRTQIS between the two proteins. The cloning of Cre in $3^{\prime}$ in phase with EGFP and the absence of mutations were verified by DNA sequencing. The functionality of the EGFP/Cre fusion protein was verified by cotransfecting COS cells with this EGFP/Cre plasmid and with the Cre activity reporter plasmid pCMV-LneoL-Betagal (a gift from Daniel Metzger, IGBMC). Further, a T2A cleavable peptide sequence (Szymczak et al., 2004) was inserted, joining the Oprm1 gene to the EGFP/Cre sequence, so that the EGFP/Cre enzyme is released from the receptor on translation of the MOR-T2A-EGFP/Cre fusion protein. The entire construct was verified by DNA sequencing before homologous recombination was performed. We then verified that the construct had not integrated randomly in the genome. Of note, no DNA sequencing or splicing analysis of the Oprm1 gene was later performed in Oprm1-Cre mice. The genetic background of all mice was 100\% C57BL/6N. Mice were group housed (maximum of five mice per cage) in a temperatureand humidity-controlled animal facility $\left(21 \pm 2^{\circ} \mathrm{C}, 45 \pm 5 \%\right.$ humidity) on a $12 \mathrm{~h}$ dark/light cycle with food and water available ad libitum. All experiments were performed in accordance with the Canadian Council of Animal Care and by the Animal Care Committees.

\section{Genotyping PCR}

For routine genotyping, the forward primer is ATATTATTTTCCCTGACGCGTTCTG; and the reverse primer is CTGAAGATTGACATTGTATCGAGGA. The PCR product for the Oprm1-Cre wild-type allele is $311 \mathrm{bp}$, and for the Oprm1-Cre knock-in allele is $387 \mathrm{bp}$ (Extended Data Fig. 1-1). 


\section{Dissection for $m R N A$ and signaling testing}

Mice were sacrificed by dislocation and the whole brain was quickly extracted and placed upside down in a chilled metal matrix (ASI Instruments). Cold razor blades were inserted into the $1 \mathrm{~mm}$ spaced coronal groove with the first most rostral one inserted at the limit of olfactory bulbs. Brain punches were dissected using 1 or $2 \mathrm{~mm}$ tissue corers and placed into microtubes, rapidly frozen, and stored at $-80^{\circ} \mathrm{C}$. A half-brain was used to prepare striatal membranes incubated with different doses of DAMGO in $\left[{ }^{35} \mathrm{~S}\right]-\mathrm{GTP} \gamma \mathrm{S}$ assay. The other half-brain was used to extract RNA in the following eight regions: dorsal striatum (DS); nucleus accumbens (NAc); habenula $(\mathrm{Hb})$; interpeduncular nucleus (IPN); ventral tegmental area (VTA)/substantia nigra (SN); cerebellum (Cer); periaqueductal gray (PAG); and spinal cord (SC). The gene expression was examined by quantitative PCR.

\section{Quantitative analysis of transcript expression}

Quantitative real-time PCR (RT-qPCR) was adapted from the study by Meirsman et al. (2016). Six hundred nanograms of RNA was reverse transcribed using the Invitrogen M-MLV Reverse Transcriptase Kit (Thermo Fisher Scientific) according to the manufacturer instructions. The cDNA was subjected to 45 cycles of amplification using LightCycler 480 SYBR I Green Master Mix (Roche) in the LightCycler 480 II Real-Time PCR System (Roche). cDNA samples were loaded in triplicate, and a no-template control reaction, with just water, was included to check for nonspecific amplification. Relative fold changes were calculated by the comparative Ct method ( $2^{-\Delta \Delta C T}$; Livak and Schmittgen, 2001) using $\mathrm{B} 2 \mathrm{M}$ as a housekeeping gene.

\section{mRNA in situ hybridization}

In situ hybridization was performed using Advanced Cell Diagnostics RNAscope probes and reagents according to the manufacturer instruction to detect mRNA encoding MOR (Oprm1) and EGFP (EGFP). Briefly, Oprm $1^{+/+}$and Oprm $1^{\text {Cre/Cre }}$ male mice were killed, and fresh brains were flash frozen in isopentane. The $10-\mu \mathrm{m}$-thick coronal sections were cut using a cryostat (Leica), directly mounted on Superfrost slides, and kept at $-80^{\circ} \mathrm{C}$ until processing. Sections were first fixed in chilled $10 \%$ neutral buffered formalin for $15 \mathrm{~min}$ at $4^{\circ} \mathrm{C}$, dehydrated by increasing gradient of ethanol bathes, and left to air dry for $5 \mathrm{~min}$. Endogenous peroxidase activity was quenched with hydrogen peroxide reagent for $10 \mathrm{~min}$, followed by protease digestion for $30 \mathrm{~min}$ at room temperature. The following sets of probes were then hybridized for $2 \mathrm{~h}$ at $40^{\circ} \mathrm{C}$ in a humidity-controlled oven (HybEZ II, ACDbio): EGFP-C1 target region 2707 (catalog \#538851, ACDbio) and Oprm1-C2 target region 1135-2162 (catalog \#315841-C2, ACDbio). Probes for Oprm1, and eGFP were revealed using respectively Opal Dye 520 and Opal Dye 570-labeled probes. Slides were then coverslipped with Vectashield mounting medium with 4',6'-diamidino-2-phenylindole dihydrochloride (DAPI) for nuclear staining (Vector Laboratories) and kept at $4^{\circ} \mathrm{C}$ until imaging.

\section{${ }^{35}$ S]-GTP $\gamma S$ binding assays}

The assay was performed as previously described by several studies (Pradhan et al., 2009; Erbs et al., 2015;
Meirsman et al., 2016) on membrane preparations from striatum. Striatum was dissected following mouse cervical dislocation, placed on dry ice, and stored at $-80^{\circ} \mathrm{C}$. To evaluate the MOR function, striatum $(n=2$ pools $\times$ four per genotype) were pooled together and membranes were prepared by homogenizing tissues in $0.25 \mathrm{~m}$ sucrose with a Polytron, followed by centrifugation at $2500 \mathrm{rpm}$ for $10 \mathrm{~min}$ at $4^{\circ} \mathrm{C}$. Samples were diluted in TMEN (Tris $50 \mathrm{~mm}$, $\mathrm{MgCl} 23 \mathrm{~mm}$, EGTA $0.2 \mathrm{~mm}$, and $\mathrm{NaCl} 100 \mathrm{~mm}, \mathrm{pH}$ 7.4) followed by an ultracentrifugation at $40,000 \times g$ for $30 \mathrm{~min}$ at $4^{\circ} \mathrm{C}$ (MLA-55 rotor, Beckman Coulter). The membrane pellet was resuspended in $0.32 \mathrm{~m}$ sucrose by 10 strokes with a potter. Membrane preparations were diluted in $800 \mu \mathrm{l}$, aliquoted, and stored at $-80^{\circ} \mathrm{C}$. Protein concentration was determined by the Bradford assay using a standard curve of bovine serum albumin and triplicate dilution of each sample. For each $\left[{ }^{35} \mathrm{~S}\right]-\mathrm{GTP} \gamma \mathrm{S}$ binding assay, $5 \mu \mathrm{g}$ of protein was used per well. Samples were incubated with variable concentration $\left(3 \times 10^{-9}\right.$ to $2 \times$ $10^{-10} \mathrm{M}$ ) of DAMGO in assay buffer containing $5 \mathrm{~mm}$ GDP and $0.1 \mathrm{~nm}\left[{ }^{35} \mathrm{~S}\right]-\mathrm{GTP} \gamma \mathrm{S}$ for $1 \mathrm{~h}$ at $25^{\circ} \mathrm{C}$. After wash and filter steps, bound radioactivity was quantified using a liquid scintillation counter (TopCount, PerkinElmer). Nonspecific binding was determined in the absence of agonist. Basal activity was determined in the presence of $10 \mu \mathrm{M}$ GTP $\gamma$ S. Calculations and sigmoidal dose-response binding curves were done using GraphPad Prism 6 (GraphPad Software).

\section{Tissue preparation and immunohistochemistry}

Mice were anesthetized with intraperitoneal injections of $100 \mu \mathrm{l} / 100 \mathrm{~g}$ cocktail containing ketamine/xylazine/ acepromazine. An intracardiac perfusion was performed with $\sim 10 \mathrm{ml}$ of ice-cold $1 \times$ Invitrogen PBS (Thermo Fisher Scientific) $\mathrm{pH} 7.4$ followed by $\sim 50 \mathrm{ml}$ ice-cold $4 \%$ paraformaldehyde (PFA; Electron Microscopy Sciences) using a peristaltic pump at $\sim 10 \mathrm{ml} / \mathrm{min}$. Brains were dissected and postfixed after $24 \mathrm{~h}$ at $4^{\circ} \mathrm{C}$ in the $4 \%$ PFA solution, cryoprotected at $4^{\circ} \mathrm{C}$ in $30 \%$ sucrose (Thermo Fisher Scientific) for $48 \mathrm{~h}$, embedded in OCT compound (Thermo Fisher Scientific), frozen, and finally stored at $-80^{\circ} \mathrm{C}$. Brains were sliced into $30 \mu \mathrm{m}$ coronal and sagittal sections using a cryostat (Leica), and sections were stored at $4^{\circ} \mathrm{C}$ in PBS. Immunohistochemistry was performed by washing the sections for $3 \times 10 \mathrm{~min}$ in PBS, then for $3 \times 10 \mathrm{~min}$ with PBS/ Triton X-100 0.1\% (PBS-T; Sigma-Aldrich), followed by $1 \mathrm{~h}$ in a blocking buffer (PBS, 3\% normal donkey serum, Triton $\mathrm{X}-1000.2 \%$ ), each at room temperature with gentle agitation. Sections were incubated overnight in blocking buffer at $4^{\circ} \mathrm{C}$ with the following primary antibodies: 1:2000 anti-green fluorescent protein (catalog \#NB100-1614, Novus; RRID: AB_523902); 1:1000 anti-MOR antibody (UMB3, catalog \#ab134054, Abcam); 1:1000 anti-dsred (catalog \#632496, Clontech; RRID:AB_10013483); or 1:1000 anti-tyrosine hydroxylase (catalog \#ab112, Abcam; RRID:AB_297840). Sections were then washed $3 \times 10 \mathrm{~min}$ in PBS-T, incubated for $2 \mathrm{~h}$ at room temperature with appropriate Alexa Fluor-conjugated secondary antibodies. Sections were washed $3 \times 10$ min in PBS-T with gentle agitation, placed in PBS, and mounted on to glass slides with Mowiol (PolyScience) and DAPI $(0.5 \mu \mathrm{g} / \mathrm{ml}$; Thermo Fisher 
Scientific; RRID:AB_2307445). The UMB3 MOR antibody showed no staining in sections from MOR knock-out mice (Extended Data Fig. 1-2).

\section{Image acquisition}

Slides were scanned on the Olympus VS120 microscope with a $10 \times$ objective. For fluorescence microscopy, an Olympus IX73 microscope with 10x or oil-immersion $60 \times$ objective was used. For confocal microscopy imaging, an Olympus FV1200 microscope with $20 \times$ or oil-immersion $60 \times$ objective, was used to take $z$-stack images.

\section{Behavioral experiments}

Morphine-induced analgesia. Mice were intraperitoneally injected with 2.5 or $5 \mathrm{mg} / \mathrm{kg}$ morphine or saline, and analgesia was tested using tail immersion (Erbs et al., 2015). Briefly, the mouse was maintained in a cylinder and the tail was immersed in a water bath set at $48^{\circ} \mathrm{C}$ with a cutoff time of $15 \mathrm{~s}$. Mice were allowed to recover for $1 \mathrm{~min}$ followed by tail immersion in a second water bath set at $52^{\circ} \mathrm{C}$ with a cutoff time of $10 \mathrm{~s}$. The baseline response was measured for tail flick before the first injection, and the morphine-induced analgesia tests were performed 45 min after the injection.

Morphine-induced locomotor sensitization. Locomotor activity was measured in Plexiglas activity boxes $(20 \times$ $20 \times 20 \mathrm{~cm}$ ) surrounded by horizontal and vertical infrared sensor beams, assisted by VersaMax software. To evaluate the morphine-induced hyperlocomotion at the first session, mice were allowed to explore the boxes for $1 \mathrm{~h}$. Mice were then injected with saline $(1 \mathrm{ml} / \mathrm{kg})$ and returned to the boxes for $1 \mathrm{~h}$ followed by an intraperitoneal injection of morphine $(40 \mathrm{mg} / \mathrm{kg})$ or saline, and activity was recorded for $2 \mathrm{~h}$. For locomotor sensitization, mice were injected twice per week with saline and placed in the boxes for $1 \mathrm{~h}$ followed by morphine $(40 \mathrm{mg} / \mathrm{kg})$ injection and activity was recorded for $2 \mathrm{~h}$. Measurements were taken on days $1,4,8,11,14$, and 18 , as adapted from the study by Darcq et al. (2012).

Stereotaxic surgery. Animals were anesthetized with $5 \%$ isoflurane for $5 \mathrm{~min}$ and maintained at $2 \%$ isoflurane. For viral Cre recombination, adult Oprm $1^{\text {Cre/Cre }}$ male mice were injected unilaterally with $100 \mathrm{nl}$ of AAV2.EF1a.DIO. mCherry (RRID:Addgene_20299) in the medial Hb [MHb; anteroposterior (AP), $-1.35 \mathrm{~mm}$; mediolateral (ML), $-0.25 \mathrm{~mm}$; dorsoventral (DV), $-2.8 \mathrm{~mm}$ ]. For optogenetic experiments, adult Oprm ${ }^{\mathrm{Cre} / \mathrm{Cre}}$ male mice were injected unilaterally with $400 \mathrm{~nL}$ of AAV2.EF1a.DIO.ChR2-mCherry (RRID:Addgene_20297) or AAV2.EF1a.DIO.mCherry in the VTA (AP, $-3.3 \mathrm{~mm}$; ML, $-0.5 \mathrm{~mm}$; DV, $-4.3 \mathrm{~mm}$ ). Two weeks after virus injection, fiber-optic ferrules $(200 \mu \mathrm{m}$; numerical aperture, 0.37) were implanted above the VTA (AP, $-3.3 \mathrm{~mm}$; ML, $-0.5 \mathrm{~mm}$; DV, $-4.1 \mathrm{~mm}$ ). The implant was secured using a first layer of Metabond followed by a layer of dental cement. Mice were allowed to recover for at least 4 weeks after infusion of virus before habituation to the optic cord and behavioral testing. The injected and implanted mice are designated as Oprm1-Cre ${ }^{\text {VTA-VTA:ChR2 }}$.

Real-time place preference. Five weeks after the viral injections, mice were placed in a custom behavioral arena (black Plexiglas, $50 \times 50 \times 25 \mathrm{~cm}$ ) divided into two identical chambers and allowed to explore each of the two chambers for $20 \mathrm{~min}$. Using an Anymaze hardware controller connected to the laser, light stimulation $(473 \mathrm{~nm}, 10 \mathrm{~mW})$ at $0,10,20$, or $40 \mathrm{~Hz}$ (10 ms pulse width) was delivered through fiber-optic implants during the duration of their time spent in the light stimulation chamber. Mice received no light stimulation in the "no stimulation" chamber. At the start of the session, the mouse was placed in the nonstimulated side of the chamber. The percentage of time spent on the paired stimulation side was recorded via a CCD camera interfaced with the Anymaze (Stoelting) software.

\section{Statistical analysis}

All data are presented as the mean SEM. Statistical analysis was assessed using $t$ tests or repeated-measures ANOVA. When ANOVA reached significance, a Tukey's HSD test was conducted. Nonsignificance was defined as $p>0.05$, and significance as $* p<0.05$, $* * p<0.01$, and $* * * p<0.001$.

\section{Results}

Unsuccessful attempts to develop transgenic mouse lines using both short and bacterial artificial chromosome promoters of the mu-opioid receptor gene (Oprm1), led us to use homologous recombination to insert the Cre recombinase gene into the Oprm1 gene locus. A knock-in strategy for the Oprm1 gene was designed (Fig. 1a) to generate a large precursor protein, which would be further cleaved to release both the native MOR protein and a functional EGFP/Cre recombinase in cells that normally express the MOR. This approach produced the Oprm1 $1^{\text {Cre/Cre }}$ (or Oprm1-Cre) mouse line, which we characterized extensively.

We first tested whether the insertion of the T2AEGFP/Cre cDNA into the Oprm1 gene locus modifies levels of gene transcription. Quantitative mRNA analysis in several brain regions, including most MOR-enriched regions, revealed that the genomic modification does not disrupt Oprm1 transcription (Fig. 1b). Using EGFP primers, we also detected the egfp transcript in Oprm $1^{\text {Cre/Cre }}$ but not Oprm $1^{+/+}$control mice, suggesting that the entire Oprm1-T2A-eGFP/Cre transcript is transcribed in the knock-in line (data not shown). We further performed double in situ hybridization using separate probes for Oprm1 and eGFP/Cre mRNAs in brain sections from Oprm $1^{\text {Cre/Cre }}$ mice (two mice, eight sections) and found colocalization of the two transcripts in all the sections examined (Fig. 1c, level of striatum).

Second, we examined expression of MOR and EGFP/ Cre proteins using immunohistochemistry in brain sections from heterozygous Oprm $1^{\mathrm{Cre} /+}$ mice. In the $\mathrm{MHb}$ (i.e., the best MOR-enriched region), we observed predominant expression of the two proteins in both basolateral and apical subregions (Fig. 1d, left) as expected (Gardon et al., 2014). Higher magnification (Fig. 1d, right panels) showed distinct subcellular distribution of the two proteins, as expected from the natural localization of MOR (cytoplasm/membrane) and EGFP/Cre (nuclear). The latter observation suggests that the T2A-EGFP/Cre 
a

Oprm1 locus

(Mus muculus, chr10)

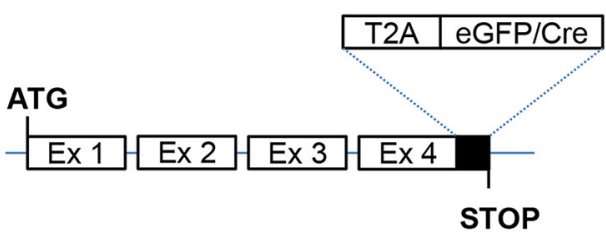

b

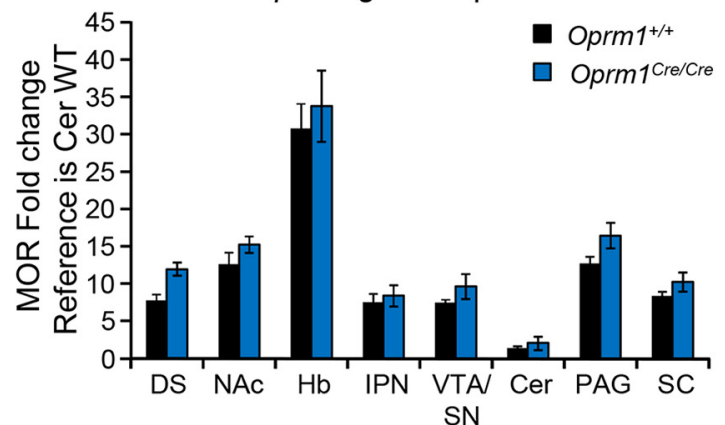

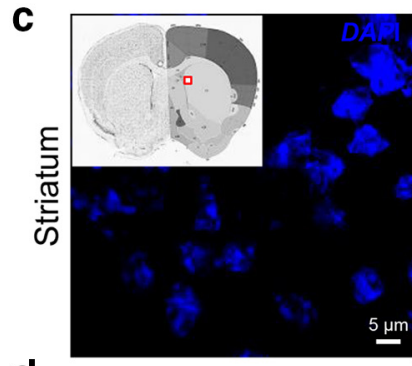
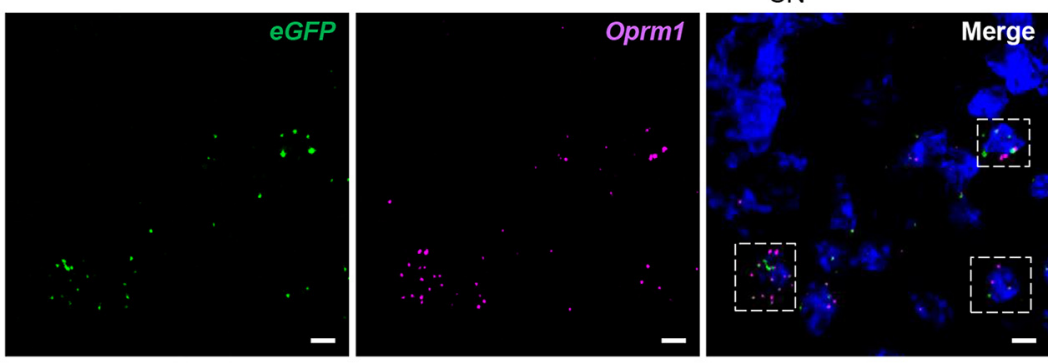

d
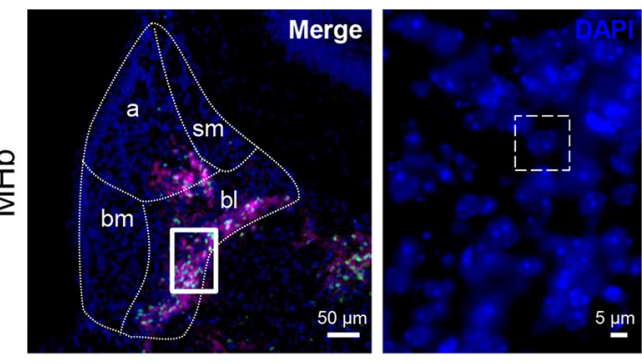

Oprm1/a647

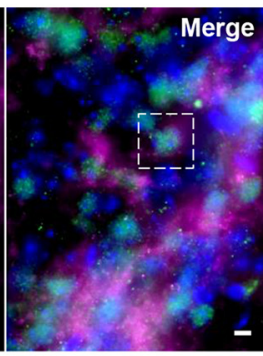

e

MOR signalling

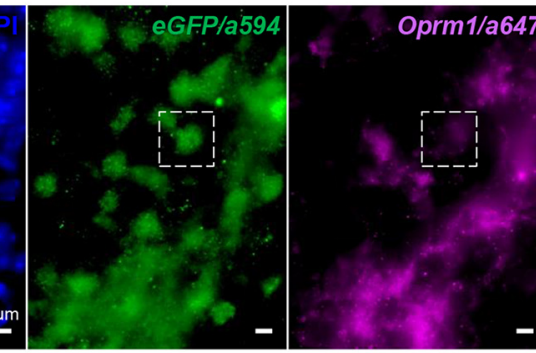

f

Morphine-induced locomotor sensitization
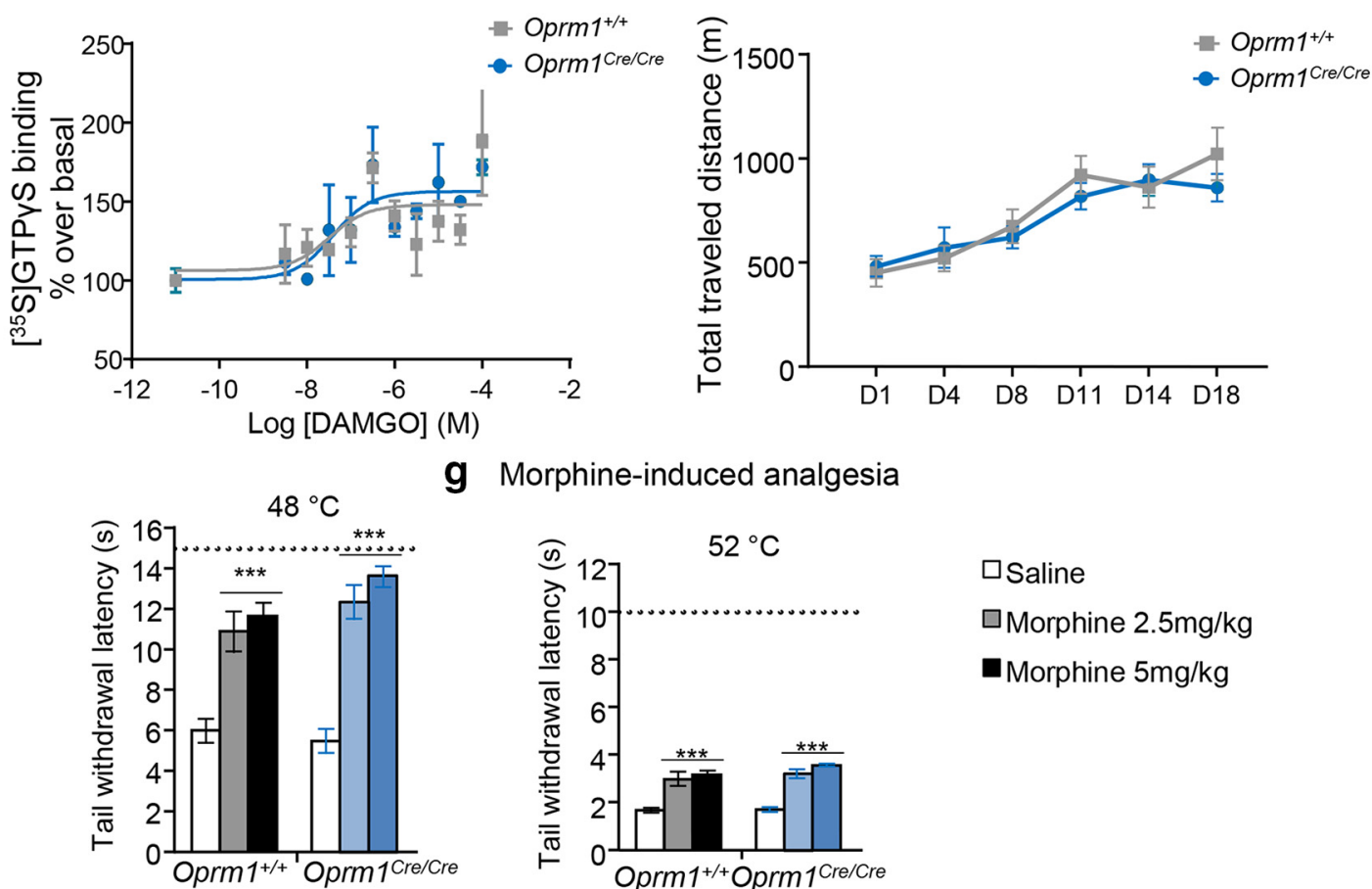

g Morphine-induced analgesia

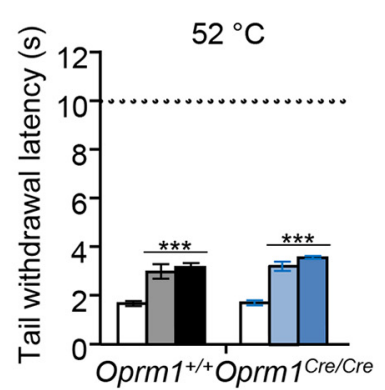

$\square$ Saline

$\square$ Morphine $2.5 \mathrm{mg} / \mathrm{kg}$

-Morphine $5 \mathrm{mg} / \mathrm{kg}$

Figure 1. Intact MOR function in the Oprm1-Cre line. a, Targeting strategy: a cDNA encoding a functional EGFP/Cre recombinase fusion protein is inserted in frame and upstream the stop codon of the Oprm1 gene. In addition, a T2A cleavable peptide sequence is joining Oprm1 gene to the EGFP/Cre sequence, so that the EGFP/Cre enzyme is released from the receptor on translation of the 
continued

MOR-T2A-EGFP/Cre fusion protein (Extended Data Fig. 1-1, Knockin (KI) genotyping strategy). $\boldsymbol{b}$, Oprm1 mRNA expression levels are identical between Oprm $1^{\text {Cre/Cre }}$ and Oprm $1^{+/+}$mice. Quantification was done by RT-qPCR in samples from DS, NAc, Hb, IPN, VTA/SN, Cer, PAG, and SC and shows comparable Oprm1 transcript levels across genotypes. c, Confocal imaging of RNAscope probes targeting eGFP (green) and Oprm1 (purple) mRNAs in addition of DAPI staining (blue) shows colocalization of the two transcripts in dorsal striatum sections of Oprm $1^{\text {Cre/Cre }}$ mice (inset). Dashed lines delimit examples of MOR-EGFP/Cre-positive neurons. Magnification, $60 \times$ with immersion oil. Scale bar, $5 \mu \mathrm{m}$. $\boldsymbol{d}$, Left, Immunohistochemistry shows EGFP/Cre and MOR protein expression in the same habenular subdivisions. Coronal brain sections of heterozygote Oprm $1^{\mathrm{Cre} /+}$ mice were stained with EGFP and MOR antibodies (Extended Data Fig. 1-2, MOR antibody validation), and fluorescence microscopy shows the expected staining mainly in basolateral (bl) and apical (a) parts of the $\mathrm{MHb}$. Bm, Basomedial; sm, stria medullaris tract. Magnification:, 10×. Scale bar, $50 \mu \mathrm{m}$. Right, Four panels at higher magnification (inset, basolateral part of the MHb), staining reveals nuclear DAPI (blue) and EGFP/Cre (green) staining, whereas MOR staining (purple) is exclusively extranuclear. Magnification, $60 \times$ with immersion oil. Scale bar, $5 \mu \mathrm{m}$. Dashed lines delimit one example of an MOR-EGFP/Cre-positive neuron. $\boldsymbol{e}$, MOR signaling is preserved in Oprm $1^{\text {Cre/Cre }}$ mice. G-protein activation was evaluated using $\left[{ }^{35} \mathrm{~S}\right]$-GTP $\gamma \mathrm{S}$ binding: DAMGO-induced G-protein activation is similar in striatal membranes to the two genotypes ( $n=2$ pools $\times 4$ striatum; $\mathrm{EC}_{50}, 324 \mathrm{~nm}$ for Oprm1 ${ }^{+/+}$and $392 \mathrm{~nm}$ for Oprm ${ }^{C r e / C r e}$; $\mathrm{E}_{\mathrm{max}}$, $148 \pm 7$ for Oprm $1^{+/+}$and $156 \pm 11$ for Oprm $\left.1^{\text {Cre/Cre }}\right) . f$, Locomotor sensitization of morphine is intact in Oprm $1^{\text {Cre/Cre }}$ mice. Mice were injected at days $1,4,8,11,14$, and 18 with morphine $(40 \mathrm{mg} / \mathrm{kg}$, i.p.). Total traveled distances recorded for $2 \mathrm{~h}$ are comparable in Oprm $1^{+/+}$and Oprm $1^{\text {Cre/Cre }}$ mice ( $n=7$ animals/group). Data are presented as the mean \pm SEM. $g$, Analgesic effects of morphine are intact in Oprm $1^{\text {Cre/Cre }}$ mice. Analgesia was assessed by tail immersion test: identical tail withdrawal latencies were measured at $48^{\circ} \mathrm{C}$ and $52^{\circ} \mathrm{C}$, in wild-type Oprm $1^{+/+}$and Oprm $1^{\text {Cre } / C r e}$ mice $45 \mathrm{~min}$ after a single saline or morphine injection $(2.5 \mathrm{or} 5 \mathrm{mg} / \mathrm{kg}$; $n=10$ animals/group). Dashed horizontal lines show cutoff at $15 \mathrm{~s}$ for $48^{\circ} \mathrm{C}$ and $10 \mathrm{~s}$ for $52^{\circ} \mathrm{C}$. Data are presented as the mean \pm SEM. $* * * p<0.001$ morphine effect compared with saline.

fusion protein was mostly cleaved, which was further supported by Western blot (data not shown) and the expected activity for the two proteins (see below).

Third, we investigated whether MOR function is intact in this mouse line. We tested MOR signaling in response to DAMGO, a MOR-selective agonist. The $\left[{ }^{35} \mathrm{~S}\right]-\mathrm{GTP} \gamma \mathrm{S}$ binding assay showed similar potency and efficacy of DAMGO in samples from the two genotypes, suggesting that MOR-mediated G-protein activation is intact in the Oprm1-Cre line (Fig. 1e). Next, we compared the two best documented in vivo effects of morphine in Oprm 1 Cre/Cre and Oprm $1^{+/+}$mice. Morphine-induced hyperlocomotion, as well as locomotor sensitization were measured in Oprm $1^{\mathrm{Cre} / \mathrm{Cre}}$ and Oprm $1^{+/+}$mice (Fig. 1f). A two-way, mixed-design ANOVA, with genotype as a between-subjects factor, and days since injection as a within-subjects factor, indicated a main effect only for days $\left(F_{(5,60)}=35.19\right.$, $p<0.001)$. The interaction term was not significant $\left(F_{(5,60)}=1.70, p>0.05\right)$. Pairwise comparisons tests were performed using a Tukey's HSD test. The mean total traveled distance at days 11,14 , and 18 was significantly higher compared with days 1,4 , and $8(p<0.001)$, and day 8 was significantly higher than day $1(p<0.05)$. Morphine therefore induced similar hyperlocomotion and sensitization in the two genotypes. Morphine analgesia was assessed using the tail immersion test (Fig. 1 g). At $48^{\circ} \mathrm{C}$, a two-factor (genotype $\times$ injection treatment) between-subject ANOVA yielded significant main effects for injection treatment $\left(F_{(2,54)}>53.77, p<0.0001\right)$. The interaction term was not significant $\left(F_{(2,54)}=1.724, p>0.05\right)$. Tukey's HSD tests computed on the main effect for treatment indicated that the mean tail withdrawal latencies were significantly increased for both genotypes and at 2.5 and $5 \mathrm{mg} / \mathrm{kg}$ morphine doses (all $p$ values $<0.001$ ). Similarly at $52^{\circ} \mathrm{C}$, a two-factor (genotype $\times$ injection treatment) between-subject ANOVA yielded a significant main effect for the treatment $\left(F_{(2,51)}>45.32\right.$, $p<0.0001)$, with no significant interaction $\left(F_{(2,51)}=\right.$ $0.453, p>0.05)$. Tukey's HSD tests indicated that mean tail withdrawal latencies were significantly increased for the two genotypes and at the two morphine doses (all $p$ values $<0.001$ ). Together, results show intact morphine effects on both activity and pain perception in mutant mice, and overall the data suggest that MOR signaling and function in vivo are maintained in the Oprm1-Cre line.

Fourth, we examined whether the EGFP/Cre fusion protein is able to mediate Cre/LoxP recombination in the Oprm1-Cre line. Of note, although the EGFP/Cre fusion has the advantage of allowing detection of the recombinase, non-EGFP fluorophores should be used when combining with other reporters. We therefore used red fluorescent reporters in the subsequent experiments. We first injected a Cre-dependent fluorescent reporter AAV2-mCherry virus in the MHb, and found a strong fluorescent signal (Fig. 2a, left) with a pattern similar to the EGFP/Cre signal (Fig. 1c) in apical and basolateral MHb. Several compartments of the IPN were also strongly labeled, indicating that the fluorescent reporter is transported along fibers to the major projection site (Fig. 2a, left), as expected (Gardon et al., 2014). To get a brain-wide view of Cre-mediated recombination in the Oprm1-Cre line, we crossed the mice with Cre-dependent reporter Rosa ${ }^{\text {IsltdTomato }}$ mice (see Materials and Methods and Movie 1). The tdTomato protein was strongly expressed in $\mathrm{MHb}$, fasciculus retroflexus, and IPN (Fig. 2a, right), with a pattern similar to that observed on Cre-dependent viral reporter expression except that areas out of the MHb-IPN pathway were also labeled. In particular, fluorescence was observed throughout the mesolimbic pathway, including striatal patches, direct pathway projections neurons, and the VTA/SN that are typical of MOR expression (Cui et al., 2014). Recombination also occurred in the central amgydala, intercalated amygdala, and the endopiriform nucleus, but not in the basolateral amygdala, concordant with sites of high MOR expression (Erbs et al., 2015). Together, these anatomic data demonstrate that the EGFP/Cre protein is functional. Further, Cre activity is found at known sites of 

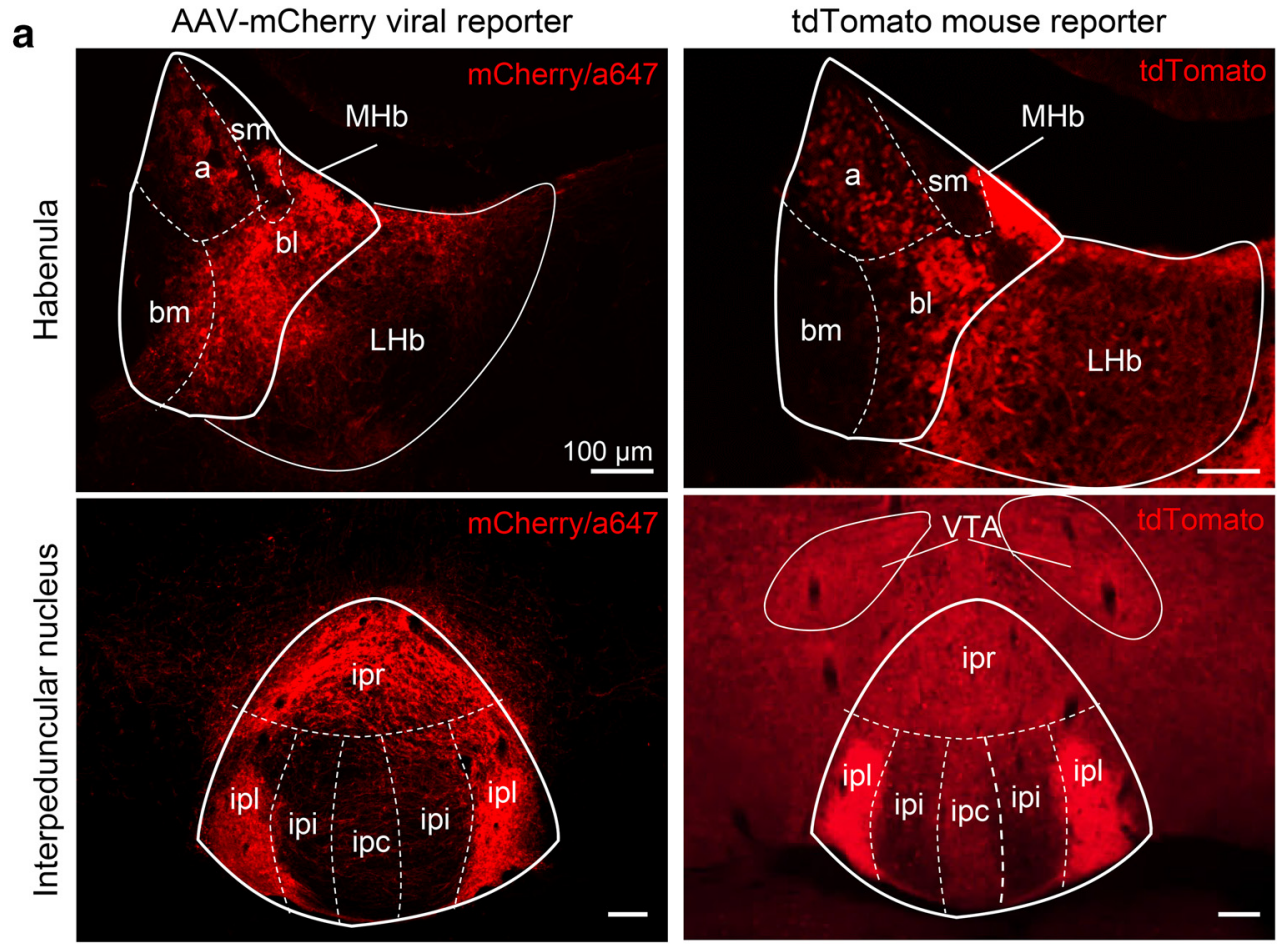

b

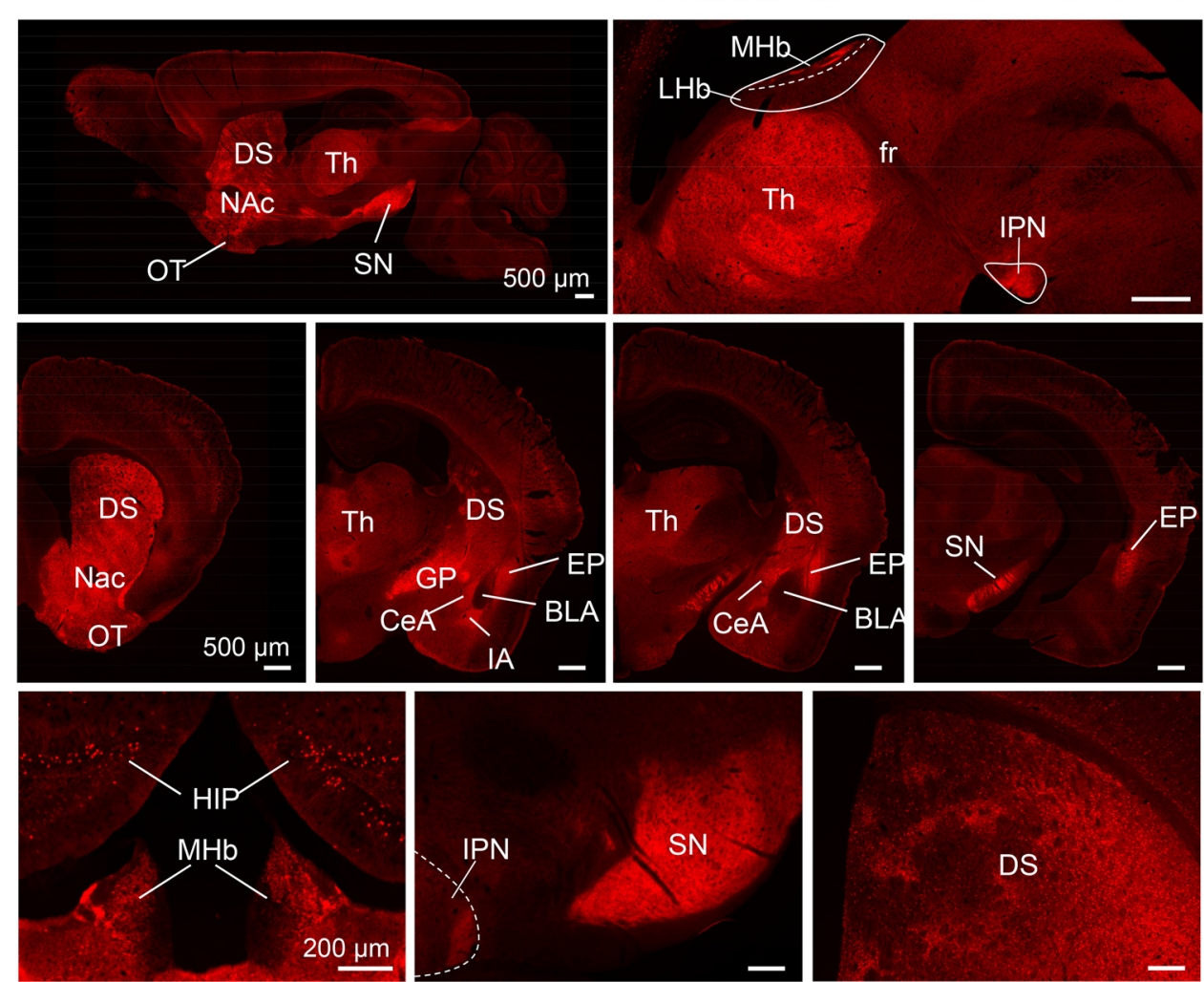

Figure 2. Cre-mediated recombination is efficient in the Oprm1-Cre line. a, Cre-mediated expression of the fluorescent reporter tdTomato in the habenula-interpeduncular pathway. Left, Cre recombination on local injection of an AAV2.EF1a.DIO.mCherry viral reporter in the $\mathrm{MHb}$; right, Cre recombination on breeding Cre-dependent tdTomato reporter mice with the Oprm1-Cre line both lead to a strong fluorescent signal apical (a) and basolateral (bl) of the $\mathrm{MHb}$, as well as in the rostral (ipr) and lateral (ipl) areas of the IPN. Scale bar, $100 \mu \mathrm{m} . \boldsymbol{b}$, Cre-mediated tdTomato expression in the adult brain of Oprm1-Cre $\times$ tdTomato mice. Top, Whole-brain sagittal views show high tdTomato expression in the thalamus, as well as the entire mesolimbic (left) and MHb-IPN (right) pathways. Scale bar, $500 \mu \mathrm{m}$. Middle, Coronal sections show strong fluorescence in the basal ganglia and thalamus, as well as in most amygdalar nuclei with the notable exception of basolateral amygdala. Scale bar, $500 \mu \mathrm{m}$. Bottom, Higher-magnification highlights both cell bodies and/or fibers patterns of labeled neurons. Scale bar, $200 \mu \mathrm{m}$. Slides were scanned on the Olympus VS120 with a $10 \times$ 
continued

objective. BLA, Basolateral amygdala; CeA, central amygdala; EP, endopiriform nucleus; fr, fasciculus retroflexus; GP, globus pallidus; HIP, hippocampus; IA, intercalated amygdala; LHb, lateral Hb; OT, olfactory tubercle; Th, thalamus.

a
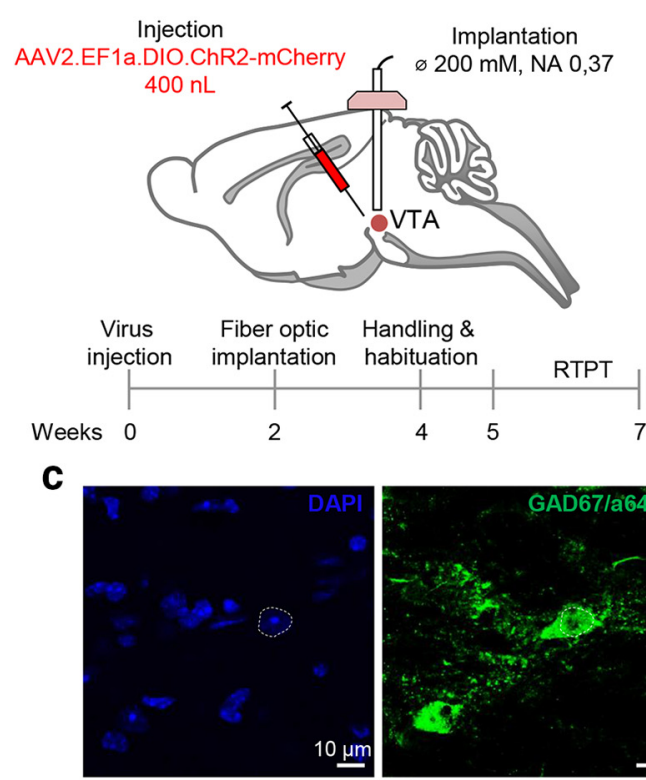

d

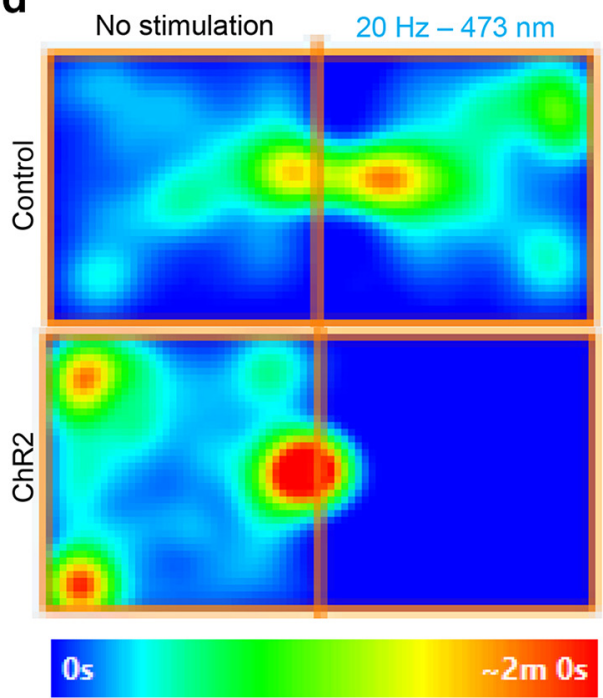

b
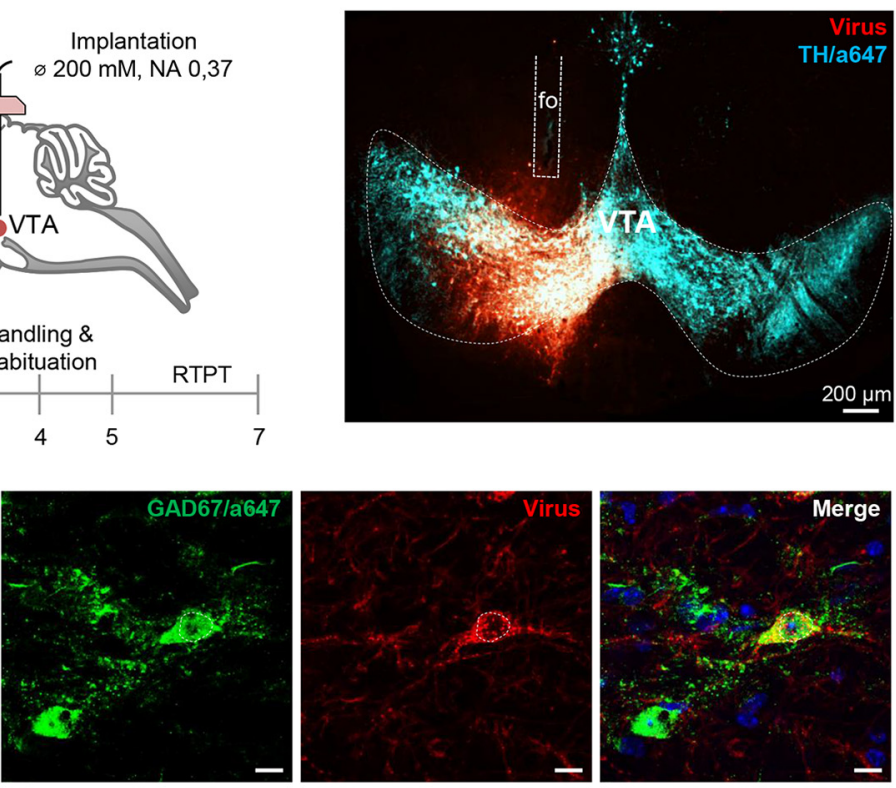

e

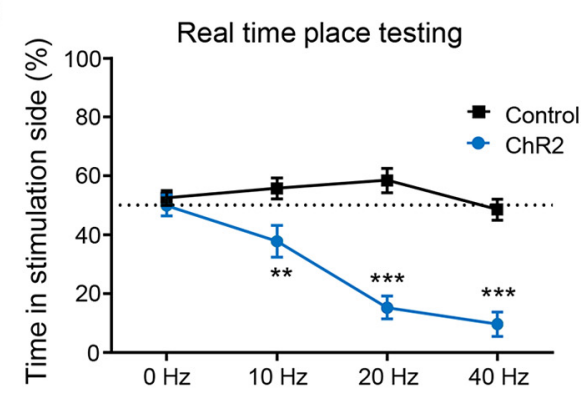

f

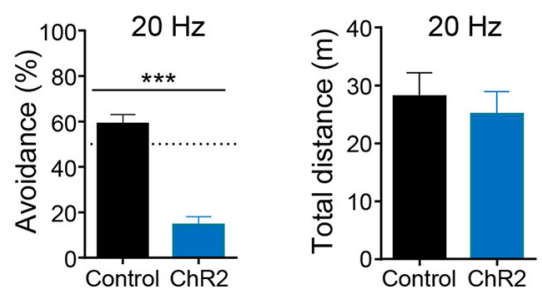

Figure 3. The Oprm1-Cre line is amenable to optogenetics. Oprm1-Cre ${ }^{\text {VTA-VTA::ChR2 }}$ photostimulation causes behavioral avoidance. a, Diagram showing viral delivery of AAV2.EF1a.DIO.ChR2-mCherry (channelorhodopsin) or AAV2.EF1a.DIO.mCherry (control) into the VTA and fiber-optic implantation above the VTA, a well as a timeline for the experimental procedure. $\boldsymbol{b}$, Representative image of viral expression (red), optic fiber implantation, and VTA dopamine cells immunostained with anti-tyrosine hydroxylase (TH)/Alexa Fluor 647 (blue). Tissues were observed on an inverted epifluorescence microscope. $\boldsymbol{c}$, Confocal imaging of VTA sections stained with GABA antibody show overlapping with viral expression. Scale bar, $10 \mu \mathrm{m}$. $\boldsymbol{d}$, Occupancy plots for representative individual at $20 \mathrm{~Hz}$. Mice were free to explore the two- chamber RTPT apparatus for $20 \mathrm{~min}$. Mice then received a blue stimulation when entering the light-paired side at $0,10,20$, and $40 \mathrm{~Hz}(473 \mathrm{~nm}, 10 \mathrm{~mW}, 10 \mathrm{~ms}$ pulse width) on 4 consecutive days, as described by Seo et al. (2016). e, Activation of VTA MOR neurons produces place avoidance. Light stimulation in Oprm1-CreVTA-VTA::ChR2 mice induced significant behavioral avoidance to the light-paired side compared with control group ( $n=7-8 /$ group). The graph shows frequency responses of mice receiving a blue stimulation when entering the light-paired side $(473 \mathrm{~nm}, 10 \mathrm{~mW}, 10 \mathrm{~ms}$ pulse width at $0,10,20$, and $40 \mathrm{~Hz} ; n=9-$ 10 , control vs ChR2). Data are expressed as the mean \pm SEM. $* * p<0.01, * * * p<0.001$. $f$, Further analysis of the $20 \mathrm{~Hz}$ simulation condition indicated significant avoidance for the light-paired side without affecting the total distance traveled $(p>0.05)$. 


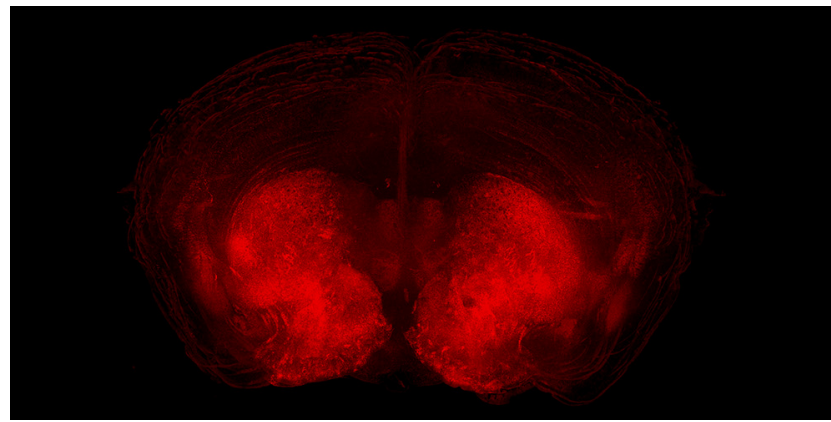

Movie 1. 3D views of the whole brain. [View online]

MOR expression, indicating accurate transcriptional control of Cre-egfp under the Oprm1 promoter. Staining patterns observed here differ from those previously reported in MOR-mCherry mice (Gardon et al., 2014; Erbs et al., 2015), as two distinct knock-in strategies were used to label either MOR-expressing cells (MOR-Cre mice; this study) or the receptor itself (MOR-mCherry mice).

Finally, we tested whether Oprm $1^{\text {Cre/Cre }}$ mice can be used for cell-specific optogenetic manipulation of MOR neurons. Earlier studies have demonstrated that optical stimulation of GABAergic interneurons in the VTA induces avoidance behavior, as a consequence of dopamine (DA) neuron inhibition (Tan et al., 2012). MOR is a $\mathrm{G}_{\mathrm{i}}$-coupled receptor expressed in these interneurons, and a best known mechanism for MOR-mediated reward is through the inhibition of these VTA GABA interneurons, an activity that in turn disinhibits DA neurons (Johnson and North, 1992; Fields and Margolis, 2015). We therefore hypothesized that optogenetic activation of MOR-EGFP/Cre-expressing neurons in the VTA of Oprm $1^{\text {Cre/Cre }}$ mice would produce a place avoidance, as did the stimulation of the entire population of VTA GABAergic neurons in the study by Tan et al. (2012). We injected a Cre-dependent AAV2channelrhodopsin virus in the VTA (Fig. $3 a, b$ ) to express ChR2 mainly in MOR/GABAergic interneurons (Fig. 3c) and tested animals using a real-time place-testing (RTPT) paradigm (Fig. 3d). A two-way ANOVA with virus as a between-subject factor and frequency as a within-subject factor yielded a significant interaction $\left(F_{(3,51)}=16.93\right.$, $p<0.001$ ). Simple effect test revealed that the Oprm1Cre VTA-VTA::ChR2 mice spent significantly less time on the side paired with light stimulation than control mice at $10 \mathrm{~Hz}(* * p<0.01), 20 \mathrm{~Hz}$, and $40 \mathrm{~Hz}(* * * p<0.001) \mathrm{com}-$ pared with control mice (Fig. $3 d, e$ ), indicating that optical stimulation triggered place avoidance. The stimulation did not affect total activity measured at $20 \mathrm{~Hz}$ (unpaired $t$ test, $t_{(14)}=1.497, p>0.05$; Fig. 3f). Together, data demonstrate that the activation of MOR-positive neurons in the VTA produce avoidance, as predicted. The Oprm1-Cre line, therefore, efficiently drives Cre-mediated recombination to modulate behavior.

\section{Discussion}

Originally developed to allow gene targeting in specific cells using Cre/LoxP recombination (Gavériaux-Ruff and Kieffer, 2007), Cre driver lines are also extensively used to label specific neuronal populations and visualize their connectivity patterns when combined with Cre-dependent fluorescent reporter mouse lines or viruses (Cai et al., 2013; Soden et al., 2014), or to monitor the activity of phenotypically defined neuronal ensembles using Cre-dependent calcium indicators (Russell, 2011). The utility of mouse Cre lines has further expanded with the advent of optogenetic and chemogenetic approaches, which allow manipulating Cre-expressing neurons to understand the circuit mechanisms underlying behavior (Fenno et al., 2011; Sternson and Roth, 2014). Transgenic Cre lines have now been generated by individual laboratories, as well as large initiatives, including the GENSAT program (Gong et al., 2007) the NIH Blueprint Cre driver Network (Taniguchi et al., 2011) and the Allen Brain Institute.

Lines providing access to the opioidergic circuitry remain limited (for review, see Darcq and Kieffer, 2018), and targeting cells responding to medicinal and abused opioid drugs is a desirable goal. To study opioid peptide-expressing cells, Cre lines using Pdyn, Penk, and Pomc gene promoters have been created (Harris et al., 2014, for Penk and Pomc lines), and Pdyn-Cre mice were used to characterize subpopulations of striatal neurons in the direct pathway (Al-Hasani et al., 2015) study $D_{1} / D_{2}$-type neuron activity balance in the nucleus accumbens (Tejeda et al., 2017), rescue MOR expression in the striatum (Cui et al., 2014), or investigate amygdala circuitry (Crowley et al., 2016). On the receptor side, one knock-in Cre line was created to gain genetic access to kappa-opioid receptor (KOR)-expressing cells (Cai et al., 2016) and used to study peripheral KOR neuron terminals in pain control (Snyder et al., 2018). This work provides a tool to access MOR neurons.

Full characterization of this novel Oprm1-Cre driver line demonstrates the following: (1) MOR signaling and function are preserved, as shown by intact G-protein activation and normal morphine-induced analgesia, locomotor stimulation, and sensitization; (2) EGFP/Cre is detectable, and the expression pattern matches MOR expression; and (3) the EGFP/Cre recombinase is functional and effectively drives both the expression of Cre-dependent reporter genes and optogenetic sensors in MOR-expressing neurons. Together with a recently published inducible MOR-CreER mouse line (Okunomiya et al., 2020), this Oprm1-Cre line is a unique tool for both mapping and functional studies of MOR-positive neurons, and will be of broad interest for opioid, pain, reward, and addiction research.

\section{References}

Al-Hasani R, McCall JG, Shin G, Gomez AM, Schmitz GP, Bernardi JM, Pyo CO, Park SI, Marcinkiewcz CM, Crowley NA, Krashes MJ, Lowell BB, Kash TL, Rogers JA, Bruchas MR (2015) Distinct subpopulations of nucleus accumbens dynorphin neurons drive aversion and reward. Neuron 87:1063-1077.

Cahill CM, Walwyn W, Taylor AMW, Pradhan AAA, Evans CJ (2016) Allostatic mechanisms of opioid tolerance beyond desensitization and downregulation. Trends Pharmacol Sci 37:963-976.

Cai D, Cohen KB, Luo T, Lichtman JW, Sanes JR (2013) Improved tools for the Brainbow toolbox. Nat Methods 10:540-547.

Cai X, Huang H, Kuzirian MS, Snyder LM, Matsushita M, Lee MC, Ferguson C, Homanics GE, Barth AL, Ross SE (2016) Generation of a KOR-Cre knockin mouse strain to study cells involved in kappa opioid signaling. Genesis 54:29-37. 
Charbogne P, Gardon O, Martín-García E, Keyworth HL, Matsui A, Mechling AE, Bienert T, Nasseef MT, Robé A, Moquin L, Darcq E, Ben Hamida S, Robledo P, Matifas A, Befort K, Gavériaux-Ruff C, Harsan L-A, von Elverfeldt D, Hennig J, Gratton A, et al. (2017) Mu opioid receptors in gamma-aminobutyric acidergic forebrain neurons moderate motivation for heroin and palatable food. Biol Psychiatry 81:778-788.

Contet C, Kieffer BL, Befort K (2004) Mu opioid receptor: a gateway to drug addiction. Curr Opin Neurobiol 14:370-378.

Corder G, Castro DC, Bruchas MR, Scherrer G (2018) Endogenous and Exogenous Opioids in Pain. Annu Rev Neurosci 41:453-473.

Crowley NA, Bloodgood DW, Hardaway JA, Kendra AM, McCall JG, Al-Hasani R, McCall NM, Yu W, Schools ZL, Krashes MJ, Lowell BB, Whistler JL, Bruchas MR, Kash TL (2016) Dynorphin controls the gain of an amygdalar anxiety circuit. Cell Rep 14:2774-2783.

Cui Y, Ostlund SB, James AS, Park CS, Ge W, Roberts KW, Mittal N, Murphy NP, Cepeda C, Kieffer BL, Levine MS, Jentsch JD, Walwyn WM, Sun YE, Evans CJ, Maidment NT, Yang XW (2014) Targeted expression of $\mu$-opioid receptors in a subset of striatal direct-pathway neurons restores opiate reward. Nat Neurosci 17:254-261.

Darcq E, Kieffer BL (2018) Opioid receptors: drivers to addiction Nat Rev Neurosci 19:499-514.

Darcq E, Befort K, Koebel P, Pannetier S, Mahoney MK, Gaveriaux-Ruff C, Hanauer A, Kieffer BL (2012) RSK2 signaling in medial habenula contributes to acute morphine analgesia. Neuropsychopharmacology 37:1288-1296.

Erbs E, Faget L, Scherrer G, Matifas A, Filliol D, Vonesch JL, Koch M, Kessler P, Hentsch D, Birling MC, Koutsourakis M, Vasseur L, Veinante P, Kieffer BL, Massotte D (2015) A mu-delta opioid receptor brain atlas reveals neuronal co-occurrence in subcortical networks. Brain Struct Funct 220:677-702.

Fenno L, Yizhar O, Deisseroth K (2011) The development and application of optogenetics. Annu Rev Neurosci 34:389-412.

Fields HL, Margolis EB (2015) Understanding opioid reward. Trends Neurosci 38:217-225.

Gardon O, Faget L, Chu Sin Chung P, Matifas A, Massotte D, Kieffer BL (2014) Expression of mu opioid receptor in dorsal diencephalic conduction system: new insights for the medial habenula. Neuroscience 277:595-609.

Gavériaux-Ruff C, Kieffer BL (2007) Conditional gene targeting in the mouse nervous system: insights into brain function and diseases. Pharmacol Ther 113:619-634.

Gong S, Doughty M, Harbaugh CR, Cummins A, Hatten ME, Heintz N, Gerfen CR (2007) Targeting Cre recombinase to specific neuron populations with bacterial artificial chromosome constructs. J Neurosci 27:9817-9823.

Harris JA, Hirokawa KE, Sorensen SA, Gu H, Mills M, Ng LL, Bohn P, Mortrud M, Ouellette B, Kidney J, Smith KA, Dang C, Sunkin S, Bernard A, Oh SW, Madisen L, Zeng H (2014) Anatomical characterization of Cre driver mice for neural circuit mapping and manipulation. Front Neural Circuits 8:76.

Johnson SW, North RA (1992) Opioids excite dopamine neurons by hyperpolarization of local interneurons. J Neurosci 12:483-488.

Levitt ES, Williams JT (2018) Desensitization and tolerance of mu opioid receptors on pontine Kölliker-Fuse neurons. Mol Pharmacol 93:8-13.

Livak KJ, Schmittgen TD (2001) Analysis of relative gene expression data using real-time quantitative PCR and the 2(-Delta Delta $\mathrm{C}(\mathrm{T})$ ) method. Methods 25:402-408.

Lutz PE, Kieffer BL (2013) Opioid receptors: distinct roles in mood disorders. Trends Neurosci 36:195-206.

Matthes HW, Maldonado R, Simonin F, Valverde O, Slowe S, Kitchen I, Befort K, Dierich A, Le Meur M, Dollé P, Tzavara E, Hanoune J, Roques BP, Kieffer BL (1996) Loss of morphine-induced analgesia, reward effect and withdrawal symptoms in mice lacking the mu-opioid-receptor gene. Nature 383:819-823.
Mechling AE, Arefin T, Lee HL, Bienert T, Reisert M, Ben Hamida S, Darcq E, Ehrlich A, Gaveriaux-Ruff C, Parent MJ, Rosa-Neto P, Hennig J, von Elverfeldt D, Kieffer BL, Harsan LA (2016) Deletion of the mu opioid receptor gene in mice reshapes the reward-aversion connectome. Proc Natl Acad Sci U S A 113:11603-11608.

Meirsman AC, Le Merrer J, Pellissier LP, Diaz J, Clesse D, Kieffer BL, Becker JA (2016) Mice lacking GPR88 show motor deficit, improved spatial learning, and low anxiety reversed by delta opioid antagonist. Biol Psychiatry 79:917-927.

Nasseef MT, Singh JP, Ehrlich AT, McNicholas M, Park DW, Ma W, Kulkarni P, Kieffer BL, Darcq E (2019) Oxycodone-mediated activation of the mu opioid receptor reduces whole brain functional connectivity in mice. ACS Pharmacol Transl Sci 2:264-274.

Okunomiya T, Hioki H, Nishimura C, Yawata S, Imayoshi I, Kageyama R, Takahashi R, Watanabe D (2020) Generation of a MOR-CreER knock-in mouse line to study cells and neural circuits involved in mu opioid receptor signaling. Genesis 58:e23341.

Pradhan AAA, Becker JAJ, Scherrer G, Tryoen-Toth P, Filliol D, Matifas A, Massotte D, Gavériaux-Ruff C, Kieffer BL (2009) In vivo delta opioid receptor internalization controls behavioral effects of agonists. PLoS One 4:e5425.

Russell JT (2011) Imaging calcium signals in vivo: a powerful tool in physiology and pharmacology. Br J Pharmacol 163:1605-1625.

Seo DO, Funderburk SC, Bhatti DL, Motard LE, Newbold D, Girven KS, McCall JG, Krashes M, Sparta DR, Bruchas MR (2016) A GABAergic projection from the centromedial nuclei of the amygdala to ventromedial prefrontal cortex modulates reward behavior. $J$ Neurosci 36:10831-10842.

Snyder LM, Chiang MC, Loeza-Alcocer E, Omori Y, Hachisuka J, Sheahan TD, Gale JR, Adelman PC, Sypek El, Fulton SA, Friedman RL, Wright MC, Duque MG, Lee YS, Hu Z, Huang H, Cai X, Meerschaert KA, Nagarajan V, Hirai T, et al. (2018) Kappa opioid receptor distribution and function in primary afferents. Neuron 99:1274-1288.e6.

Soden ME, Gore BB, Zweifel LS (2014) Defining functional gene-circuit interfaces in the mouse nervous system. Genes Brain Behav 13:2-12.

Sternson SM, Roth BL (2014) Chemogenetic tools to interrogate brain functions. Annu Rev Neurosci 37:387-407.

Szymczak AL, Workman CJ, Wang Y, Vignali KM, Dilioglou S, Vanin EF, Vignali DA (2004) Correction of multi-gene deficiency in vivo using a single "self-cleaving" $2 \mathrm{~A}$ peptide-based retroviral vector. Nat Biotechnol 22:589-594.

Tan KR, Yvon C, Turiault M, Mirzabekov JJ, Doehner J, Labouèbe G, Deisseroth K, Tye KM, Lüscher C (2012) GABA neurons of the VTA drive conditioned place aversion. Neuron 73:1173-1183.

Taniguchi H, He M, Wu P, Kim S, Paik R, Sugino K, Kvitsiani D, Kvitsani D, Fu Y, Lu J, Lin Y, Miyoshi G, Shima Y, Fishell G, Nelson SB, Huang ZJ (2011) A resource of Cre driver lines for genetic targeting of GABAergic neurons in cerebral cortex. Neuron 71:995-1013.

Tejeda HA, Wu J, Kornspun AR, Pignatelli M, Kashtelyan V, Krashes MJ, Lowell BB, Carlezon WA Jr, Bonci A (2017) Pathway- and cellspecific kappa-opioid receptor modulation of excitation-inhibition balance differentially gates D1 and D2 accumbens neuron activity. Neuron 93:147-163.

Volkow ND, Koroshetz WJ (2019) The role of neurologists in tackling the opioid epidemic. Nat Rev Neurol 15:301-305.

Weibel R, Reiss D, Karchewski L, Gardon O, Matifas A, Filliol D, Becker JA, Wood JN, Kieffer BL, Gaveriaux-Ruff C (2013) Mu opioid receptors on primary afferent nav1.8 neurons contribute to opiate-induced analgesia: insight from conditional knockout mice. PLoS One 8:e74706.

Williams HD, Trevaskis NL, Charman SA, Shanker RM, Charman WN, Pouton CW, Porter CJ (2013) Strategies to address low drug solubility in discovery and development. Pharmacol Rev 65:315-499.

World Health Organization (2017) Curbing prescription opioid dependency. Bull World Health Organ 95:318-319. 